\title{
Vocal Cord Polyp
}

National Cancer Institute

\section{Source}

National Cancer Institute. Vocal Cord Polyp. NCI Thesaurus. Code C3440.

A non-neoplastic polypoid swelling of the vocal cord mucosa. It is usually unilateral and caused by excessive use of the voice. 